Article

\title{
Firefighter Observations of "Surprising" Fire Behavior in Mountain Pine Beetle-Attacked Lodgepole Pine Forests
}

\author{
Kevin Moriarty ${ }^{1}$, Antony S. Cheng ${ }^{2,3, * \mathbb{C}}$, Chad M. Hoffman ${ }^{3}$, Stuart P. Cottrell ${ }^{4}$ and \\ Martin E. Alexander ${ }^{5}$ \\ 1 Boise District, Bureau of Land Management, 3948 South Development Avenue, Boise, ID 83705, USA; \\ kmoriarty@blm.gov \\ 2 Colorado Forest Restoration Institute, Campus Delivery 1472, Colorado State University, Fort Collins, \\ CO 80523-14, USA \\ 3 Department of Forest and Rangeland Stewardship, Campus Delivery 1472, Colorado State University, \\ Fort Collins, CO 80523-1472, USA; c.hoffman@colostate.edu \\ 4 Department of Human Dimensions of Natural Resources, Campus Delivery 1480, Colorado State University, \\ Fort Collins, CO 80523-1480, USA; stuart.cottrell@colostate.edu \\ 5 Wild Rose Fire Behaviour, 180 - 50434 Range Road 232, Leduc County, AB T4X 0L1, Canada; mea2@telus.net \\ * Correspondence: tony.cheng@colostate.edu; Tel.: +1-970-491-1900
}

Received: 30 May 2019; Accepted: 15 June 2019; Published: 18 June 2019

\begin{abstract}
The recent mountain pine beetle outbreak affecting lodgepole pine forests in the Rocky Mountains has created a novel fire environment for wildland firefighters. This paper presents results from an examination of firefighters' observations of fire behavior in post-outbreak lodgepole pine forests, with a focus on what they considered surprising from a fire behavior standpoint and how this in turn affected their suppression tactics. The surprises in fire behavior experienced by firefighters during the red phase of post-outbreak forests included an elevated level of fire spread and intensity under moderate weather and fuel moisture conditions, increased spotting, and faster surface-to-crown fire transitions with limited or no ladder fuels. Unexpectedly, during the gray phase in mountain pine beetle-attacked stands, crown ignition and crown fire propagation was observed for short periods of time. Firefighters are now more likely to expect to see active fire behavior in nearly all fire weather and fuel moisture conditions, not just under critically dry and windy situations, and across all mountain pine beetle attack phases, not just the red phase. Firefighters changed their suppression tactics by adopting indirect methods due to the potential fire behavior and tree-fall hazards associated with mountain pine beetle-attacked lodgepole pine forests.
\end{abstract}

Keywords: case study; Colorado; crown fire; firefighter safety; firefighting; fire environment; fire weather; spotting; social science research; wildland fuels; Wyoming

\section{Introduction}

The mountain pine beetle (MPB; Dendroctonus ponderosae) outbreak between the mid-1990s and 2009 affected approximately 17.6 million hectares (ha) of lodgepole pine (Pinus contorta var. latifolia) forests of Western Northern America [1]. The large-scale tree mortality associated with the outbreak has raised concerns amongst public officials, citizens, and fire managers about increased wildfire threats to neighboring communities, domestic water supplies, and recreation areas [2,3]. For wildland firefighters, post-outbreak MPB forests represent novel fire environments in terms of their current scale and severity that may impact the effectiveness of fire suppression operations and compromise firefighter safety now and for decades to come. While scientific research on fire behavior in post-MPB 
outbreak forests has primarily focused on crowning potential e.g., [4-9], scant attention has been paid to the broader range of fire behavior and effects characteristics such as rate of fire spread, surface fire intensity, spotting, fire size, and fire severity [10-14]. Page et al. [15] portray these characteristics as collectively acting to affect resistance-to-control-i.e., constructing and holding control line in the face of an expanding fire perimeter. A free-burning fire that has a high resistance-to-control has the potential to grow to a very large size and impact socially and economically important values and assets (e.g., homes, water supplies, electricity transmission systems), thereby requiring large commitments of human, financial, and technological resources [16].

Previous anecdotal observations by firefighters have suggested that fire behavior in post-outbreak MPB forest stands can be considered as quite surprising [15,17], indicating that the observations of fire behavior made by wildland fire personnel in these situations was unexpected. This gap between expectation and observation can impact firefighter safety [18,19], and is critical to the understanding of informed fire management strategies and operations. To date, however, there has been a lack of systematic research connecting fire behavior characteristics in MPB-attacked lodgepole pine forests to changes, or lack thereof, in firefighter strategies and tactics.

In this paper, we present and discuss results from a qualitative social science research examination of "surprising" fire behavior observed by wildland firefighters in post-outbreak MPB lodgepole pine forest fires in Northern Colorado and Southern Wyoming, and the subsequent changes in their decisions and actions resulting from these so-called surprises. "Surprising" fire behavior is defined here as fire behavior that is unexpected by firefighters based on their prior knowledge and experience. By focusing on surprises, we can derive a better understanding of the key issues and challenges that fires in post-outbreak MPB forests pose to firefighters. This knowledge can also inform fire managers and policy-makers who make decisions regarding the allocation of human, financial, and technological resources to fire management tasks.

In this study, we investigated three main lines of questioning of wildland firefighters:

- How did your expectations of fire behavior in post-outbreak MPB lodgepole pine forests compare to actual direct observations in the field?

- What surprised you about the observed fire behavior and why?

- Did your suppression tactics change after directly observing fire behavior in post-outbreak lodgepole pine forests and if so how?

We begin by conceptualizing "surprise" in the context of wildland fire to provide the rationale for our research approach. This is followed by a description of research methods employed to collect and analyze data about firefighters' experiences, surprising observations, and changes in their subsequent actions. Results are then presented, accompanied by selected quotes illustrating the nature of the surprises with respect to fire behavior observed by firefighters. We conclude with a discussion about how and why firefighters' observations of surprising fire behavior in wildland fires in MPB-attacked forests contributed to a broader understanding of the ecological, social, and political consequences wrought by the MPB outbreaks in lodgepole pine forests in recent years.

\section{Conceptualizing "Surprise" in the Context of Wildland Fire}

Surprises are critical occurrences in how people experience and understand the world, for they represent something outside of one's expectations of how something should work and, therefore, challenge one to make sense of the new phenomenon [20,21]. A potential consequence of surprise is what organizational theorist Karl Weick has termed a "collapse in sensemaking in organizations" [18], wherein traditional organizational roles, routines, and identities are ill-suited to respond adequately to a hazardous event, leading to disastrous consequences. Weick derived this concept from his examination of the 1949 Mann Gulch Fire tragedy in Northwestern Montana, in which 12 smokejumpers and a fire guard died [18]. 
Over the past two decades, firefighters' observations of surprising behavior have been documented with increased frequency [15,22-24]. The interest in firefighters' perspectives about unexpected or surprising fire behavior has been driven by the perceived concerns among fire managers that fire behavior in recent years exceed historical precedence and are becoming more extreme due to changing climatic conditions and wildland fuel conditions [24]. As such, firefighters' observations, perceptions, and experiences during wildland fire events are potentially valuable sources of information for adapting safe and effective fire management strategies and operations in novel environments such as MPB-attacked forests. In particular, uncovering and addressing the implications of surprises is a hallmark of so-called high reliability organizations-organizations in which members routinely and intentionally resist oversimplification and unsupported assumptions, and develop a deep repertoire to manage unexpected occurrences $[25,26]$, among other attributes.

Despite this potential value, firefighter perceptions, experiences, and behaviors has received scant attention in comparison to the physical and ecological aspects of wildland fire. In the 1950s and 1960s, wildland fire case studies were used as a source of information for research and training, and to elevate fire management practices. In such case studies, multiple information sources were utilized, including firefighters' recollections about they observed and what actions they took in response to observations, in order to reconstruct a wildfire incident and advance firefighter safety guidelines [27]. Wildfire case studies have declined in recent decades due to other priorities and limited budgets. Several researchers have suggested that case studies can generate significant insight for both fire managers and fire researchers alike [27-30]. Observational information, even if incomplete due to depreciating memory, can still provide nuanced information on fire behavior. In addition, documenting firefighters' mental cues that inform fire-ground decisions can help elucidate what fire behavior firefighters might expect verses what they actually observe [31,32].

More recently, researchers have elicited the observations, interpretations, and actions of firefighters engaged in a broad range of fire incidents versus a single case study using ethnographic methods, such as in-depth interviews, story-telling, document analysis, and participant-observation during incidents [33,34]. Regarding observations of surprising fire behavior, Wall et al. [24] utilized a method to elicit micro-narratives using story prompts about a recent fireline experience, including narratives about erratic or inexplicable fire behaviors. These narratives emerged from a broad range of topographic, fuel, and weather conditions. More specific to MPB-attacked forests, Durbin et al. [19] utilized direct observation, participant-observation, informal interviews, and semi-structured interviews of firefighters, foresters, and loggers to elicit perceptions about, and responses to the hazards posed by working in MPB-attacked forests, namely, the unpredictability of falling snags. The focus of this research was on the heightened situational awareness and additional safety triggers required of forest workers.

While recent wildfires in MPB-attacked lodgepole pine forests in the Western US have prompted heightened scientific research activity into the physical aspects of forest fires in such fuel complexes, there remains a lack of systematic research on firefighter observations of surprising fire behavior in MPB-attached forests and the implications of these observations on subsequent fire management strategies and tactics. The large spatial extent of the MPB outbreak in Western North America and prospect of future wildfires in this novel environment warrants deeper understandings about the changes needed in fire management policies, strategies, and tactics to protect firefighters from injury and even death while at the same time achieving fire management goals [15]. 


\section{Materials and Methods}

\subsection{Wildfire Case Selection}

The scope of the study encompassed wildfires in lodgepole pine-dominated forests in Northern Colorado and Southern Wyoming that are within MPB outbreaks that occurred between 1996 and 2013 [35]. Fires that burned on National Forest System lands managed by the US Forest Service (USFS), federal public lands managed by the Bureau of Land Management, National Park Service, and non-federal lands were considered for the study. Wildfires that met these criteria were compiled using the Rocky Mountain Geographic Area Coordination Center website archived wildfire database (https://gacc.nifc.gov/rmcc/incident_info.php).

Two periods of fire activity have occurred in the past two decades: 2001-2003 and 2008-2012. Fire perimeters for both time periods were located using the GeoMAC Viewer website (www.geomac. gov/viewer/viewer.shtml), a US Geological Survey MODIS based program. Fire perimeters were then overlaid with aerial detections of MPB in lodgepole pine using ArcGIS, based on information gathered by USFS Forest Health Protection for the Rocky Mountain region. Because firefighter recollections of fire behavior during the 2001-2003 fire seasons would have likely decayed with time, they are perhaps prone to incompleteness (i.e., recall of specific details is diminished). Hence, 13 wildland fires that occurred during the 2010-2012 fire seasons were the focus of interviews (Figure 1 and Table 1).

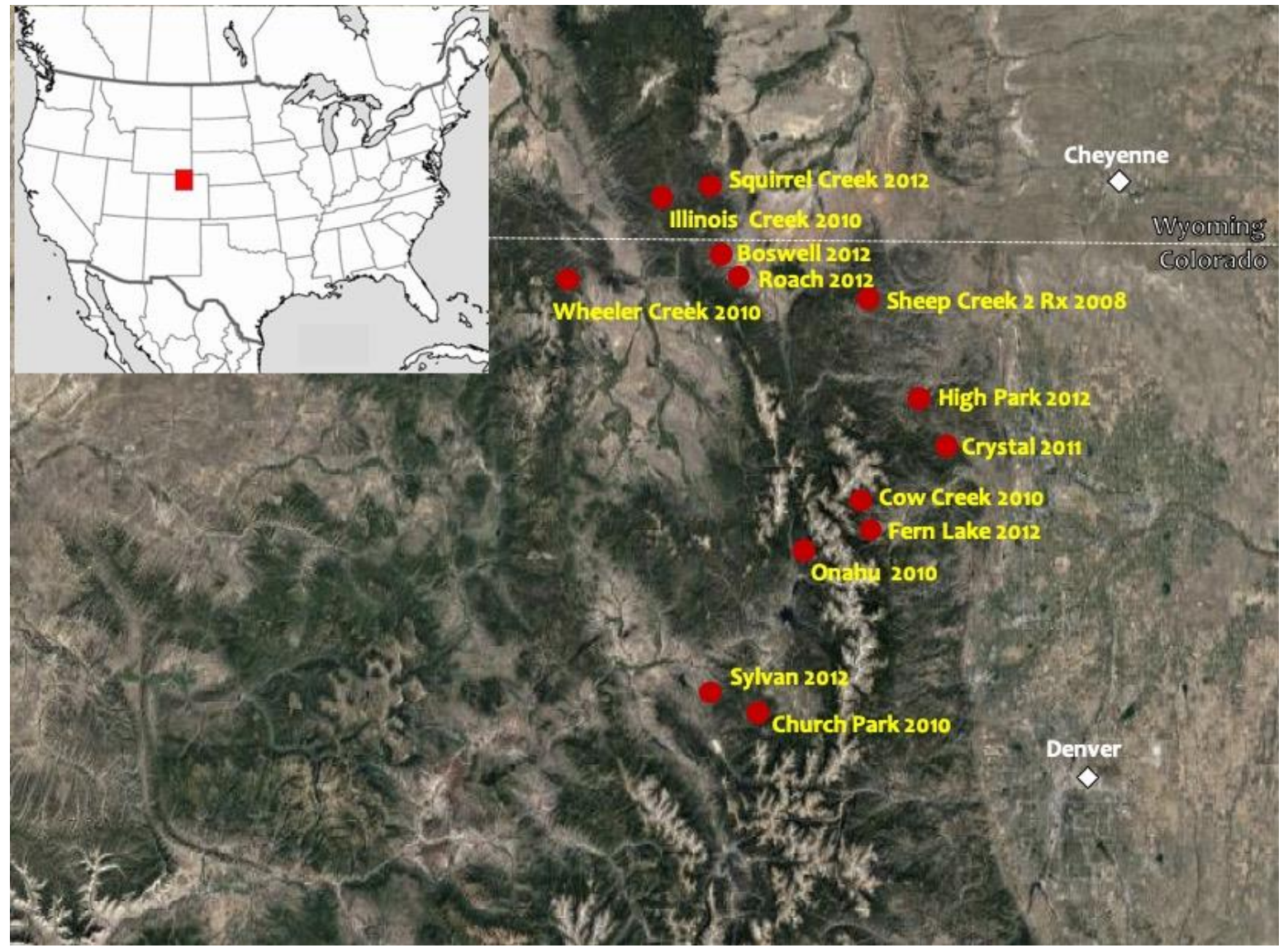

Figure 1. Map of the study area and location, name, and year of mountain pine beetle (MPB)-attacked lodgepole pine forest fires encompassed by the study. 
Table 1. MPB-attacked lodgepole pine forest fires encompassed by the study.

\begin{tabular}{|c|c|c|c|c|c|c|c|c|c|}
\hline Incident Name & Location ${ }^{A}$ & $\begin{array}{c}\text { Date } \\
\text { (Month/Year) }\end{array}$ & Fire size (ha) & MPB Phase & $\begin{array}{l}\% \text { MPB } \\
\text { Mortality }\end{array}$ & $\begin{array}{l}\text { Predominant Stand } \\
\text { Composition } \mathrm{C}\end{array}$ & $\begin{array}{c}\text { Surface Fuel } \\
\text { Characteristics } \\
\end{array}$ & Topography & Weather Variables ${ }^{\mathrm{E}}$ \\
\hline Boswell & Larimer County, CO/ARP & $8 / 2010$ & 36 & Red & $50-90$ & LP & $\begin{array}{c}\text { Needlecast, grass, } \\
\text { moderate } 1000-\mathrm{h}\end{array}$ & Steep drainages & $\begin{array}{l}\text { Pre-frontal winds, } \\
\text { moderate conditions }\end{array}$ \\
\hline Church Park & Grand County, CO/ARP & $10 / 2010$ & 192 & $\begin{array}{c}\text { Mixed } \\
\text { (red/gray) }\end{array}$ & $50-80$ & LP, ES, SF & $\begin{array}{c}\text { Needlecast, grass, } \\
\text { moderate 1000-h }\end{array}$ & $\begin{array}{l}\text { Mountain-side, } \\
\text { ridgeline }\end{array}$ & $\begin{array}{l}\text { Pre-frontal winds, } \\
\text { moderate conditions }\end{array}$ \\
\hline Cow Creek & $\begin{array}{l}\text { Larimer County, } \\
\text { CO/RMNP }\end{array}$ & $6 / 2010$ & 486 & Mixed & $0-50$ & LP, ES, SF & $\begin{array}{l}\text { Needlecast, grass, } \\
\text { moderate 1000-h }\end{array}$ & Steep drainages & $\begin{array}{c}\text { Early summer, } \\
\text { moderate conditions }\end{array}$ \\
\hline Crystal & $\begin{array}{l}\text { Larimer County, } \\
\text { CO/Private }\end{array}$ & $4 / 2011$ & 1190 & Gray & $10-20$ & PP, LP & $\begin{array}{l}\text { Needlecast, grass, } \\
\text { 1000-moderate h }\end{array}$ & Ridgeline & $80 \mathrm{~km} \mathrm{~h}^{-1}$ gusts \\
\hline Fern Lake & $\begin{array}{l}\text { Larimer County, } \\
\text { CO/RMNP }\end{array}$ & $10 / 2012$ & 1416 & Gray & $40-60$ & LP & $\begin{array}{l}\text { Needlecast, grass, } \\
\text { heavy } 1000-\mathrm{h}\end{array}$ & $\begin{array}{l}\text { Mountain-side, } \\
\text { subalpine }\end{array}$ & $\begin{array}{l}\text { Multiple wind events } \\
\text { moderate conditions }\end{array}$ \\
\hline High Park & Larimer County, CO/ARP & $6 / 2012$ & 35,338 & Red & $50-80$ & PP, LP & $\begin{array}{c}\text { Needlecast, limited } \\
\text { 1000-h }\end{array}$ & $\begin{array}{l}\text { Steep slopes, } \\
\text { ridgeline }\end{array}$ & $\begin{array}{c}\text { Multiple wind events } \\
\text { drought }\end{array}$ \\
\hline Illinois Creek & Albany County, WY/MBR & $9 / 2010$ & 49 & Red & $50-90$ & LP, ES & $\begin{array}{c}\text { Needlecast, limited } \\
1000-\mathrm{h}\end{array}$ & Flat, small drainages & $\begin{array}{c}\text { Wind event, } \\
\text { moderate conditions }\end{array}$ \\
\hline Onahu & $\begin{array}{l}\text { Larimer County, } \\
\text { CO/RMNP }\end{array}$ & $9 / 2010$ & 12 & Gray & $80-100$ & LP & $\begin{array}{l}\text { Grass, standing dead } \\
\text { stems }\end{array}$ & Flat, small drainages & $\begin{array}{l}\text { Drought, moderate } \\
\text { conditions }\end{array}$ \\
\hline Roach & Larimer County, CO/ARP & $8 / 2012$ & 47 & Mixed & $60-90$ & LP & $\begin{array}{c}\text { Needlecast, moderate } \\
1000-\mathrm{h}\end{array}$ & Flat, small drainages & $\begin{array}{c}\text { Drought, moderate } \\
\text { conditions }\end{array}$ \\
\hline Sheep Creek 2 Rx & Larimer County, CO/ARP & $2008,2011^{\text {B }}$ & 61 & Red & $50-70$ & LP & $\begin{array}{c}\text { Needlecast, limited } \\
1000-\mathrm{h}\end{array}$ & $\begin{array}{c}\text { Small drainages, } \\
\text { ridgelines }\end{array}$ & $\begin{array}{l}\text { Within Rx } \\
\text { prescription }\end{array}$ \\
\hline Squirrel Creek & Albany County, WY/MBR & $7 / 2012$ & 4421 & Red & $50-70$ & LP & $\begin{array}{c}\text { Needlecast, limited } \\
\text { 1000-h }\end{array}$ & Flat, small drainages & $\begin{array}{c}\text { Multiple wind events } \\
\text { drought }\end{array}$ \\
\hline Sylvan & Grand County, CO/ARP & $5 / 2012$ & 0.5 & Gray, downed & $90-100$ & $\mathrm{LP}, \mathrm{SF}$ & $\begin{array}{l}\text { Needlecast, grass, } \\
\text { heavy } 1000-\mathrm{h}\end{array}$ & $\begin{array}{l}\text { Steep drainages, } \\
\text { ridgeline }\end{array}$ & Moderate conditions \\
\hline Wheeler & Jackson County, CO/BLM & $8 / 2010$ & 1 & Mixed & $70-100$ & LP & $\begin{array}{c}\text { Needlecast, moderate } \\
1000-\mathrm{h}\end{array}$ & Flat, small drainages & Moderate conditions \\
\hline
\end{tabular}

${ }^{\mathrm{A}}$ ARP $=$ Arapaho-Roosevelt National Forest and Pawnee National Grassland; BLM = Bureau of Land Management; MBR = Medicine Bow-Routt National Forest; and RMNP = Rocky Mountain National Park. ${ }^{B}$ The Sheep Creek 2 prescribed burn was conducted in two separate years, 2008 and 2011. ${ }^{C}$ ES $=$ Engelmann spruce; LP = lodgepole pine; PP = ponderosa pine; and $\mathrm{SF}=$ subalpine fir. ${ }^{\mathrm{D}}$ 1000-h fuels refer to dead-down roundwood fuels at least 7.6 to $20 \mathrm{~cm}$ in diameter (Deeming et al. 1977). ${ }^{\mathrm{E}}$ Moderate conditions refers to both fuel moisture and weather conditions. 


\subsection{Interview Sample and Protocol}

Interview subjects were identified using a network-sampling approach [36], targeting firefighters deployed to 2010-2012 fires in the geographic area circumscribed by the study. An initial list was developed by key informants at the USFS Rocky Mountain Region (R-2) office and through the authors' professional networks within the fire management and operations communities in Northern Colorado and Southern Wyoming. We purposefully sampled for firefighters with extensive training and experience, having held positions such as fire management officer, assistant fire management officer, engine boss, and crew boss. These included federal and non-federal personnel. Firefighters were categorized by operational positions in the chain of command and the particular wildland fires they had observed. These individuals were asked to identify other individuals with direct experience in post-MPB outbreak fires that met the selection criteria. This process of individual referrals across firefighters' networks stopped when there was complete overlap of information for the fires identified. Potential respondents were then solicited to participate in the study via an email invitation that included the interview questions. Fire behavior reports, unit logs, incident reports, photos, and videos from InciWeb (http://inciweb.nwcg.gov/) and other websites were brought to interviews to assist with recollection.

A semi-structured interview guide was used to elicit what the firefighter had observed that they considered surprises in fire behavior at the time of their incident engagement, and how their observations led to changes in operational planning and tactics on the fires for which they were deployed. A pilot interview was first conducted with a wildland firefighter to assess the effectiveness of the interview protocol in eliciting observations of fire behavior. This led to only minor word changes. A total of 28 interviews of wildland firefighters were conducted, involving seven different federal, state, county, city and non-profit agencies. Interviews were conducted between October 2012 and September 2013. Interviews lasted 45-90 minutes and were digitally recorded and transcribed to texts for coding and analysis.

\subsection{Coding}

Interview texts were coded pursuant to grounded theory analysis [37] using NVivo qualitative analysis software version 10 [38]. Grounded theory is the philosophy and methodology of social science involving the systematic construction of theory emerging from thematic patterns in data collected by researchers regarding a situation or phenomenon [37]. In essence, theories are "grounded" in the data rather than developed a priori. Grounded theory was selected as the appropriate method for our study because there was little in the way of existing understanding about fire behavior in MPB-attacked lodgepole pine forests to predict what would be considered surprising to firefighters.

Individual interview texts were read sequentially, and text segments were inductively assigned open codes (i.e., simple words or phrases that summarize the theme of the segment). As this text coding accumulated, codes were iteratively modified as texts were compared with each other [39]. Once codes were consistently assigned across themes, they were grouped into a coding tree according to their similarity [39]. Each branch of the coding tree represents categories of firefighter observations and correspond to the axial coding phase as described by Strauss and Corbin [37]. This iterative, inductive process integrated collection of similarly-themed codes that encapsulated the broadest range of firefighters' experiences, surprising observations, and subsequent changes in fire management strategies and operational tactics. This selective coding step generated the key themes described in the following section.

\section{Results}

All 28 firefighter (FF) interviewees worked on multiple fires encompassed by the study (Table 1). The average experience level was 14.6 seasons and interviewees occupied various positions on fires included in the study (Table 2). Information on MPB phase, percent mortality, stand and fuel conditions, topography, and fire weather for each fire were identified using firefighter observations, available reports, and spatial data on vegetation and topography. 
Table 2. Agency affiliations, seasons of wildland firefighting experience, fire incident engagement, and position(s) held on fires by those firefighters (FF) interviewed in this study.

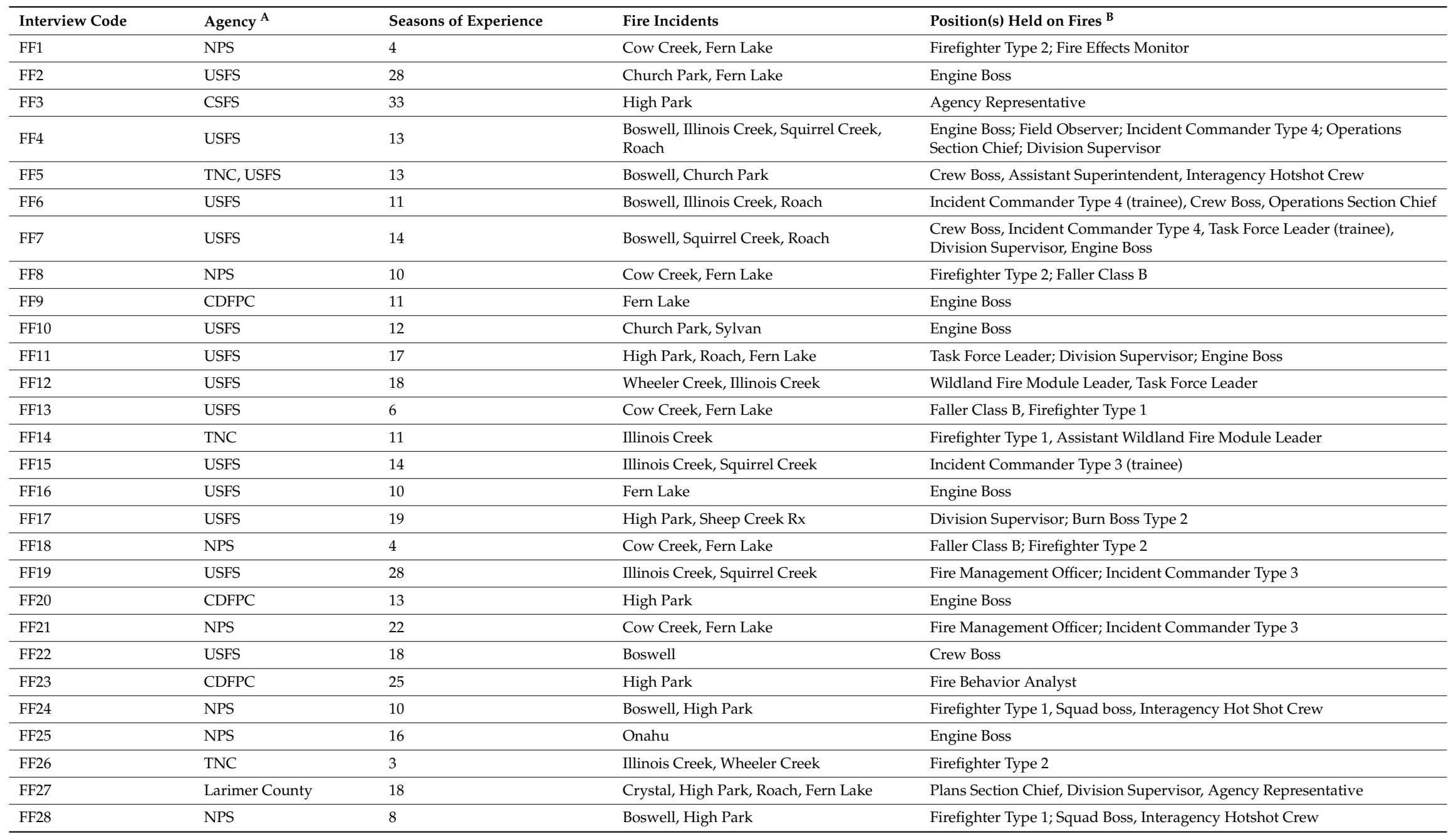

A CDFPC = Colorado Division of Fire Prevention and Control; CSFS = Colorado State Forest Service; NPS = National Park Service; TNC = The Nature Conservancy; and USFS = United States Forest Service. ${ }^{\mathrm{B}}$ Position(s) held on fires correspond to the wildland fire qualification categories identified by the National Wildfire Coordinating Group (NWCG 2013 ). 


\subsection{Observations of Surprising Fire Behavior}

Eight types of surprising fire behavior were observed by the interviewees (Table 3). Firefighters observed surprising fire behaviors in 11 of the 13 fires encompassed by this study. Only the 2010 Church Park and 2011 Crystal wildfires reportedly did not exhibit instances of surprising fire behavior specifically linked to MPB conditions. By far, the most surprising fire behaviors that firefighters observed were fast passive and active crowning under moderate fuel moisture and weather conditions across all MPB stages; 19 of 28 interviewees considered such fire behavior as surprising. As one interviewee (FF12, 2010 Illinois Creek Fire) noted:

"The transition from the surface fire to group torching or single tree torching initiated really fast. Considering the environmental conditions that we had, 32\% relative humidity $[R H]$ and temps of $50{ }^{\circ} \mathrm{F}\left[10^{\circ} \mathrm{C}\right]$. Normally if there were conditions of $15 \% \mathrm{RH}$ with $70^{\circ} \mathrm{F}\left[21^{\circ} \mathrm{C}\right]$, I could see that initiation like it did and faster than what it did. But to be able to burn under those conditions and not lose your fire per se, I think that's what's significant about what this points out, how flammable it is, at such a low intensity, moderate weather condition."

Nine interviewees were surprised at the prolific spotting in red-stage stands (Figure 2a), including short range spotting just beyond the advancing flame front such as observed on the 2010 Wheeler Creek Fire and the longer range spotting displayed on the 2010 Boswell Fire. "Spotting" refers to the ignition of new fires from firebrands transported downwind from the primary fire. Firefighters expected spotting potential to increase but were still perplexed by the degree of spotting. Increased spotting potential was identified as leading to more complex and hazardous conditions on most of the fires included in the study. As one interviewee (FF12, 2010 Wheeler Creek Fire) was to note:

"[This] just reinforced what I've been seeing with these fires as far as all the spotting and the spotting getting out in front. Having to chase all that stuff, from the little quarter sized stuff to the helmet size stuff, and having to manage all that in addition to the main fire-yeah, I think we will see more of that.

I think that's just more of that material available in the convection column of the fire."

Firefighters noted faster transitions from surface-to-crown fire propagation in the red MPB phase than expected; seven firefighters observed such fire behavior on the 2010 Illinois Creek and Boswell wildfires, and the 2012 High Park and Fern Lake wildfires as well as the Sheep Creek 2 prescribed fire (Rx) unit in 2008 and 2011. Most firefighters expected quick transition but were still surprised at just how fast the surface-to-crown fire transition occurred, as one interviewee (FF24, 2012 High Park Fire) expressed:

"We knew that if it got in the red needles that it would obviously torch out and spread. But I guess I was surprised how fast it happened, the initiation. It was almost instantaneous."

Four interviewees were surprised at how readily the fire moved from the ground surface to the tree crowns with limited fuels surrounding trees in the red phase, including fire moving directly up the boles of trees or directly from the surface fuels into the overstory canopy (Figure 2c-e).

As one of these four interviewees (FF04, 2010 Illinois Creek Fire) expressed it:

"There wasn't much down on the ground in the red needle stands. The conception I had after all the beetle stuff came out, is how is it going to get into the crowns? Red-needle trees are going to burn pretty well. But it has to get to the crowns first. The regeneration maybe? The fire did have some ladder fuels to get up into the crowns, but that was still a ways away from the initial push, about 100 acres [40 hectares] away. Once the heat started going, the red needles, even the boles of the trees, were burning. It didn't need ladder fuels for ground-to-crown transition."

Crown fire initiation with limited ladder or bridge fuels contradicts conventional wisdom taught in agency training courses and was considered surprising fire behavior by four firefighters interviewed in this study. 
Contrary to expectations, six interviewees noted limited fire perimeter growth in both red and gray MPB phases, considering the driving factors that typically sustain active fire behavior activity like wind, slope or continuous fuel (Figure 2f). As one of the six interviewees (FF03, 2012 High Park Fire) who reported on this matter stated:

"Well, what we have been told was to expect a really active crown fire. But when I tried to locate where the fire edge was, at least where the crown fire edge was, I was trying to figure out why it didn't advance to places I expected. I concluded pretty fast that it still needed slope and a continuous run of fuel. It wasn't like a grass fuel model that would spread in every direction in canopies; it still needed an alignment with winds and slopes."

Wildfires that seemed to have large growth potential did not produce expected results. Instead, active crown fire runs that would promptly drop to the forest floor, leaving firefighters perplexed.

Active crown fire propagation was noted by three interviewees in mixed stands of red and gray phases (Figure 2a,b) on the 2010 Boswell and Illinois Creek wildfires, and the 2012 Roach and Fern Lake wildfires, and was not considered as conventional wisdom. According to one of these interviewees (FF04, 2010 Boswell and Illinois Creek wildfires and 2012 Roach Fire):

"On the three fires we're talking about, there's a good mix between red and gray, maybe a little heavier on gray. The gray phase didn't seem to really make a difference to go to a crown fire than the red. Both phases seem to have an ability to have crown runs for short amounts of time."

In the standing dead, gray phase stands, only one interviewee observed fire activity that exceeded expectations-when fire was established by ignition of either small limbs or in the crotch formed between the limbs and the stem bole. This type of fire behavior phenomena diverges from most predictive models which do not account for standing dead tree stems. As the interviewee (FF25, 2010 Onahu Fire) noted:

"Even though there was minimal residence time [ the time duration in which flames burn in one place before spreading to other unburned fuels] around the base of the dead lodgepole, trees were easily ignited. We were watching embers get lifted, lofted into crotches of trees. Within thirty minutes of visible flame, the tree was falling in half. We later felled and surveyed the tree, and it was pretty well dried and rotten in on the inside, but the outside of the tree was still fairly solid."

The scientific literature suggests high-intensity surface fires are more likely once standing dead MPB-attacked trees fall to the ground in large numbers [3-6,10,11]. However, on the 2012 Sylvan Fire, a small wildfire in the advanced gray-phase exhibiting large quantities of dead-down woody fuels, one firefighter was still surprised by the intensity of the heat energy released and how difficult the fire was to suppress. As the interviewee (FF10, 2012 Sylvan Fire) noted:

"On the Sylvan Fire, it was jack-straw like you would not believe. And that jack straw stuff, you can get starts in the grasses that might've been there with the original stand. You get that grass cured and all those dead trees all over the place, and the wind pushing through that-it was a pretty intense fire.

Not a crown fire, but still surprisingly hot."

In this quote, "jack straw" refers to the jumbled heap of fallen dead trees in the years following a forest mortality event; the term comes from a game in which straw or thin strips of wood is let fall in a heap and players extract each piece without disrupting the pile. Fires with excessive amounts of dead-down MPB-attacked trees were fairly novel to the firefighters interviewed and were comparable to the intensities and durations experienced with the burning of large debris piles. 

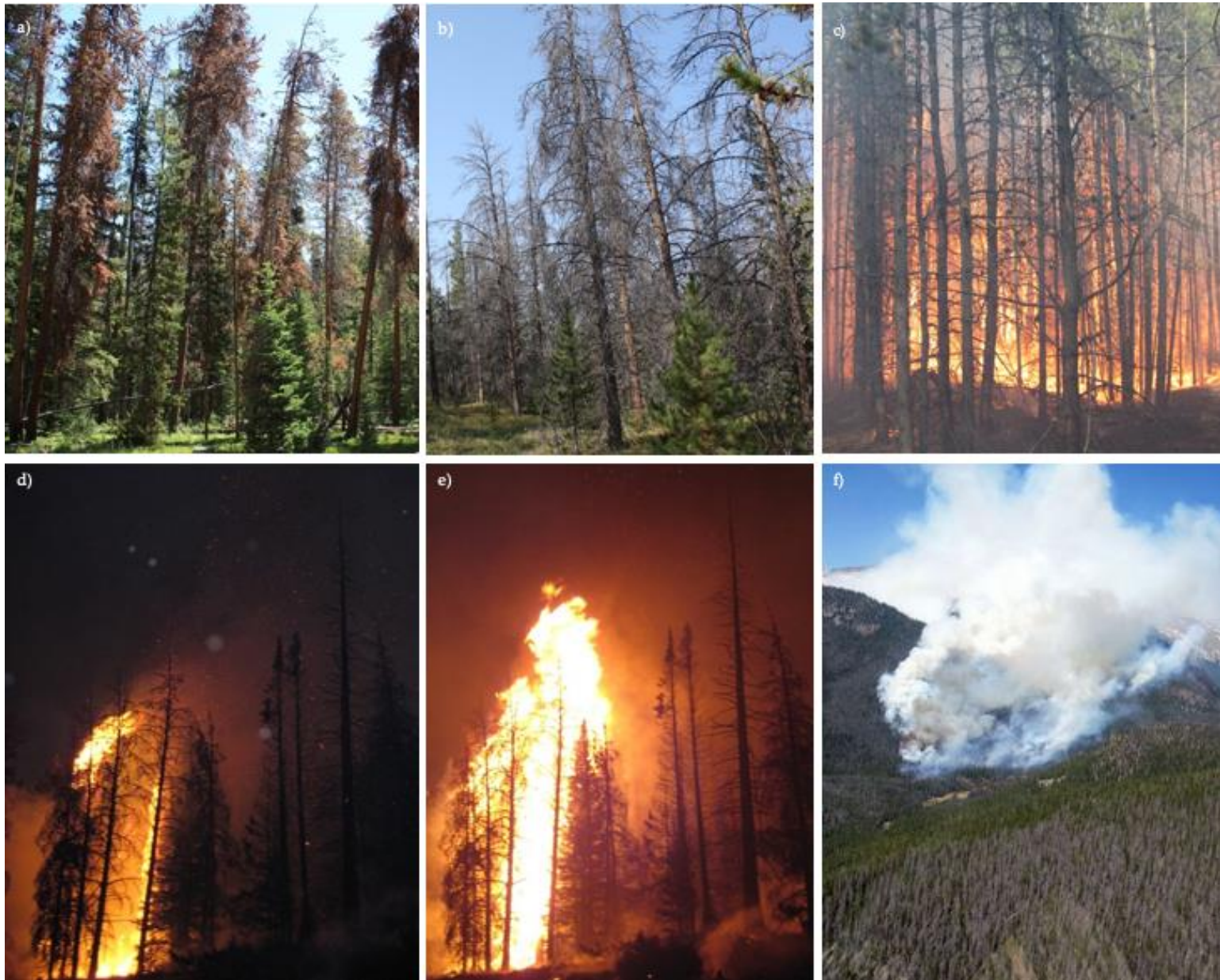

Figure 2. Examples of photos used during interviews with wildland firefighters. (a) red phase of MPB-attacked lodgepole pine forest, Colorado State Forest State Park (photo: Tony Cheng); (b) grey phase of MPB-attacked lodgepole pine forest, Fraser Experimental Forest (photo: Tony Cheng); (c) Wheeler Fire (photo: Southern Rockies Fire Module, The Nature Conservancy); (d,e) Church Park Fire (photo: National Interagency Fire Center InciWeb); (f) Big Meadow Fire, Rocky Mountain National Park (photo: National Park Service).

Table 3. Surprising fire behavior characteristics in post-mountain pine beetle outbreak fires by MPB phase.

\begin{tabular}{|c|c|c|c|c|c|}
\hline \multirow{2}{*}{ Surprising Fire Behavior } & \multicolumn{3}{|c|}{ MPB Phase } & \multirow{2}{*}{$\begin{array}{c}\text { Incidents in Which Surprises } \\
\text { Were Observed }\end{array}$} & \multirow{2}{*}{$\begin{array}{c}\text { Number of } \\
\text { Observations }\end{array}$} \\
\hline & Red & Gray & Old & & \\
\hline Increased spotting & $\mathrm{x}$ & & & $\begin{array}{c}\text { Boswell, Illinois Creek, Squirrel } \\
\text { Creek, High Park, Fern Lake, } \\
\text { Roach }\end{array}$ & 9 \\
\hline Faster surface-to-crown fire transition & $\mathrm{x}$ & & & $\begin{array}{l}\text { Boswell, Fern Lake, High Park, } \\
\text { Illinois Creek, Sheep Creek 2Rx }\end{array}$ & 7 \\
\hline Lack of fire perimeter growth & $\mathrm{x}$ & $\mathrm{x}$ & & Boswell, Illinois Creek, Roach & 6 \\
\hline $\begin{array}{l}\text { Crown fire transition with limited or } \\
\text { no ladder fuels }\end{array}$ & $x$ & & & $\begin{array}{c}\text { Illinois Creek, High Park, Sheep } \\
\text { Creek } 2 \text { Rx }\end{array}$ & 4 \\
\hline Intense heat & & & $\mathrm{x}$ & Sylvan, Wheeler Creek & 2 \\
\hline
\end{tabular}




\subsection{Change in Operational Fire Practices Based on the Surprises in Fire Behavior Experienced}

Three categories of what would be considered surprising fire behavior in MPB-killed lodgepole pine stands were identified as contributing to altering operational tactics on wildfires: (1) increased spotting activity, (2) faster surface-to-crown fire transition times, and (3) intense heat from concentrations of dead-downed tree stems. In the latter two categories, firefighters could not engage the fire directly because of increased threat to their personal safety. Observations of increased spotting along with increased crowning fire behavior and intense heat resulted in more indirect attack methods, including the use of aircraft operations, regardless of topography and accessibility.

Overall, interviewees were in agreement on less engagement with wildfires in MBP-attacked forests and favored the use of mechanical equipment and aircraft over deploying firefighters with hand tools and chain saws to the task of fire suppression. For example, on the 2012 High Park Fire, feller-bunchers, machinery commonly used in tree harvesting operations, were deployed to clear trees to assist a multi-division burnout operation adjacent to high MPB-mortality lodgepole pine stands; "burnout" refers to the intentional ignition of fuels ahead of a wildfire to reduce fire behavior and prevent further fire spread. Durbin et al. [19] found this same tendency in their study of firefighters in MPB fuel complexes. Fixed-and rotary-wing aircraft were also found to be very useful on several of the MPB fires examined in the present study. On the 2012 High Park Fire, in addition to retardant and water drops, aerial ignition with a helicopter-mounted flame-thrower was used on ridge tops that exhibited high levels of MPB-related tree mortality, while interagency (Type I) hotshot crews conducted burnouts from the bottom of the slope with hand-held drip torches. On the three largest wildfires involved in the study (i.e., Fern Lake, High Park, and Squirrel Creek wildfires in 2012), firefighters commented on non-regional Type 1 incident command teams wanting to aggressively approach the fire but not fully appreciating the various MPB-related hazards. During all three wildfires, non-regional team decision-makers eventually utilized advice received from local fire operations personnel and eventually employed more indirect attack strategies, an action similar to that observed by Durbin et al. [19].

Hazards unrelated to fire also played a significant role in the decision-making process, most notably the tree-fall hazard associated with MPB-killed trees. The firefighters interviewed noted that interagency hotshot crews devoted considerable time to mitigate tree-fall hazards, not just conducting fire suppression operations. Tree-fall hazard also affected mop-up operations; when high winds were present, mop-up work was either greatly reduced or ceased altogether. Interestingly, the tactics recommended by firefighters generally remained unchanged between MPB-attacked stands and those that had not been attacked; trees killed by MPB were simply regarded as one more hazard that needed to be mitigated against by firefighters on the fireline [40,41]. For example, the fire management teams on 2012 Fern Lake Fire went through several sand table exercises-a tactical decision game simulation using a miniature three-dimensional terrain model with various props to represent assets or liabilities [42] — to approach this fire that included MPB-attacked fuel complexes.

In summary, MPB-affected trees are just one of many mitigation issues facing firefighters as they attempt to engage in wildfire suppression. Because of so many hazards, interviewees recommend that incident management teams take a continuous monitoring approach, coupled with minimal fire crew engagement.

\section{Discussion}

The MPB outbreak in Northern Colorado and Southern Wyoming has generated a high degree of concern over wildfire risks and hazards, and interest in crafting effective fire management strategies and operational tactics. While scientific research has produced valuable insights with respect to potential fire behavior in MPB-attacked lodgepole pine stands, there has been, with few exceptions e.g., [6,15], a lack of systematic examination of how these novel, new fuel complexes might impact firefighters' sense making and fire suppression actions on the fireline. Through our professional interactions with wildland firefighters in Northern Colorado and Southern Wyoming, it was apparent that firefighters are directly observing both wildfires and prescribed fires in a variety of post-MPB outbreak lodgepole 
pine forests, with many individuals having observed multiple fires under different weather, fuel, and topographic conditions. Given the relative novelty of these events, examining firefighters' experiences, surprises, and subsequent changes in operational decisions can improve not only future operational planning and tactics, but enhance firefighter safety, and provide public officials and the general public with better information of what to expect. The present qualitative social science study of firefighters' experiences on recent MPB fires in Northern Colorado and Southern Wyoming is an attempt to fill this gap. We chose to focus on surprises in fire behavior, since unexpected occurrences are more meaningful to inducing changes in fire management strategies and operational tactics.

Two caveats warrant attention. Although the fires encompassed by this study represents the census of firefighters' observations of MPB fires that occurred from 2008 to 2012 in Northern Colorado and Southern Wyoming, the small number of MPB fires burning under different levels of MPB-related tree mortality, MPB-attack phases, topographic characteristics, fuel moisture and weather conditions, and the small number of observations for each fire, does not permit generalizations about fire behavior across all post-MPB outbreak lodgepole pine forests. The lack of controls and replication makes this an exploratory study rather than providing definitive results. Secondly, the semi-structured nature of the interviews of firefighters relied on self-reporting based on memory. Self-reporting is a persistent challenge in social science research because responses are prone to inaccuracy or exaggeration [43,44]. Furthermore, memory recall of dangerous, high-risk events can be compromised due to the "fog of war" syndrome that can cloud cognitive performance [45]. We attempted to overcome these issues by recording observations from multiple firefighters for each MPB fire and analyzing patterns common across observations. However, for three of the MPB fires under study, the Onahu Fire, Sheep Creek 2 $\mathrm{Rx}$, and Sylvan Fire, we were able to solicit only one interviewee each. We also chose to emphasize surprising observations of fire behavior as a way to access highly notable instances of fire behavior activity witnessed by the interviewees. Exceptional occurrences tend to stick out in people's memories and may have more credence [43].

Results from our analysis have a number of implications for fire training, fire management strategies, operational tactics, and fire research. First, firefighters' expectations about fire behavior across different physiographic, fuel, and weather conditions evolves through their own experiences and through their engagement in social networks in the fire operations community. Experience has been found to be an essential factor in hazardous situation response [32,46,47]. Burrows [48] maintains that most wildland firefighters base their expectations of how a fire will behave largely on experience and, to a lesser extent, on fire behavior guides or models. If this is indeed the case, then it is worth reiterating the points made by Gisborne [49] regarding the value of experienced judgment:

"For what is experienced judgment except opinion based on knowledge acquired by experience? If you have fought forest fires in every different fuel type, under all possible kinds of weather, and if you have remembered exactly what happened in each of these combinations, your experienced judgment is probably very good. But if you have not fought all sizes of fires in all kinds of fuel types under all kinds of weather then your experience does not include knowledge of all the conditions."

The importance of experience and informal social networks within the fire operations community warrants attention concerning how knowledge about potential fire behavior characteristics in MPB-attacked forests is introduced and transmitted to firefighters. While formal training and agency protocols are vital to establishing consistent operational standards, communications during incidents tend to occur in rapidly-changing situations with high uncertainty. This is especially challenging when firefighters from different organizations with different cultures and experiences with wildland fires engage in an incident [32,46,50], like what occurred on the Fern Lake, High Park, and Squirrel Creek wildfires during the 2012 fire season. Observations of surprising fire behavior in particular may confound this communication and learning, thereby posing a barrier to high reliability practices. Indeed, prior research into high reliability practices among wildland fire managers suggests a lack of attention to surprising behavior [26,51,52]. Our research suggests that emphasizing surprising fire behavior during cross-organizational peer-learning and training sessions can help ameliorate 
hazardous situations in fires burning in MPB-attacked lodgepole pine forests, thereby leading to appropriate and safe responses.

Second, integral to firefighters' evolution of expectations and subsequent strategies and operations are the decisions immediately resulting from their observations of surprising fire behavior. Displays of fire behavior like passive and active crown fire development, increased spotting activity, and at times, faster surface-to-crown fire transitions turned out to be more prevalent than expected under moderate fuel moisture and weather conditions. Such events become surprises because they defy what is expected from prior experience and information gleaned from peers, and force individuals to make decisions about changes in their work behavior [53]. In this regard, the surprises in fire behavior observed by the firefighters in our study were characterized as such because they resulted in decisions that altered their engagement tactics. Split-second immediate responses during high-hazard situations tends to be reactionary, and subsequent decisions and actions become a part of the situation itself $[31,53]$. In worst-case scenarios, this cascade of decisions and actions can lead to disastrous consequences. Pre-fire planning and training experiences should include contingency decisions for the range in potential fire behavior on MPB fires, such as those articulated in Page et al. [15].

The third implication from our study is that firefighters' observations of increased spotting activity and rapid transition in fire activity from surface fuels to surface and crown fuels in the red phase are leading to changes in fire suppression strategies and tactics favoring indirect approaches to fire suppression. Indirect attack methods may result in larger fire perimeters, longer duration fires, and, accordingly, higher suppression costs. Additionally, due to the prevalence of tree-fall hazards and intense surface fire heat loads, firefighters are more likely to establish control lines far from the active fire edge, conduct extensive burn-out operations, and allow the fire to propagate into those areas, thereby increasing final fire size. Mop-up is likely to be more limited, allowing fires to burn longer. Incident commanders are also more likely to rely on mechanical equipment and aircraft, adding to financial costs.

This scenario is potentially at odds with wildfire managers' preferences and societal expectations that wildland fires receive active fire suppression [16], although specific situations where homes, communities, and high-valued resources and assets such as water supplies that are in imminent danger may warrant more direct attack actions. In Northern Colorado and Southern Wyoming, with the exception of the 2012 High Park Fire, the MPB fires in our study occurred fairly distant from population centers and communities. In the future, in this region and in other areas throughout Western North America affected by MPB outbreaks, fires in MPB fuel complexes may pose a challenge to direct attack strategies and affect societal expectations. Such fires have the potential to become extreme wildfire events or "megafires"-i.e., fires that resist control, rapidly grow in size, last for many weeks, threaten large numbers of highly valued resources and assets, and incur high financial costs [54,55].

While the number of fires observed and number of observations involving surprises in fire behavior were small, such observations can nevertheless be informative to scientific research. For example, most surprising were the passive and active crown fires in all MPB phases under moderate fuel moisture and weather conditions across a variety of topographic situations. Such observations are consistent with some predictions of increased crowning potential in the red phase $[7,8,11,12]$, but are counter to other studies [5,56,57]. As suggested by Hicke et al. [7], Hoffman et al. [8,12] and Stephens et al. [58], these differences may be due to variability in canopy and surface fuel characteristics, the level of mortality or the spatial and temporal variability in mortality rates. Empirical evidence remains limited concerning the conditions and mechanisms for crown fire in MPB-attacked forests $[59,60]$.

The surprising observations of limited fire perimeter growth, especially in the red phase, suggests that specific weather and topographic conditions associated with the fire environment can affect surface fire spread or active crown fire development regardless of the MPB phase and degree of tree mortality. Lodgepole pine tree canopies in the red phase may be more flammable as a result of decreases in fuel moisture content and chemical changes [8,10,61,62], but other limiting factors like low surface fire intensity and non-continuous fuel strata may override fire perimeter growth and active crown 
fire development $[6,8]$. The firefighters in our study concluded that fire perimeter growth can still be limited by fuel, weather, and topographic factors.

Fire behavior predictions typically employ simplified characterizations of conditions (i.e., solely red phase vs. solely gray phase, pure stands of even-aged lodgepole pine), although [12] is an exception. Current research has concluded that present-day operational fire behavior prediction models under-predict crown fire behavior and are generally not suitable for MPB stands $[6,8,63,64]$, although exceptions founded upon empirical data do exist [65]. The majority of the fires examined encompassed heterogeneous forest conditions containing a mix of red, gray, and old phases, and mixed-aged lodgepole pine stands with components of ponderosa pine (Pinus ponderosa), subalpine fir (Abies lasiocarpa), and Engelmann spruce (Picea engelmannii). Additionally, the varying rates of tree-fall have created complex surface fuel conditions over space and time. Combining advances in fire behavior simulators, firefighter observations, and a rigorous program of experimental burning and wildfire monitoring in different types of MPB-attacked forest conditions is necessary to improve our fire behavior knowledge in such fuel types and in turn our decision-making ability [15].

In closing, ethnographic research of firefighters' observations of surprising fire behavior can provide valuable knowledge about the novel fire environments created by the MPB outbreaks and inform decisions about effective, safe fire management strategies and operational procedures. The firefighters that participated in our study directly observed fire behavior across diverse conditions, which can be an indispensable source of information with respect to further scientific inquiry. However, fire operations systems do not incorporate consistent data collection of fire behavior observations and the associated environmental conditions. Fire behavior information garnered from a wildfire is unfortunately rarely published [28]. Employing technologies such as fire record notebooks or mobile photo and video equipment to fire crews [66] can complement firefighting training and are now available at low-cost compared to the cost of fire suppression operations. The more we can learn about fires occurring in these novel fire environments, the better-prepared and informed firefighters, fire managers, scientists, and policy-makers will be to recommend and take appropriate actions when it comes to dealing with both wanted and unwanted fires.

Author Contributions: Conceptualization: A.S.C., K.M., and C.M.H.; methodology: K.M., S.P.C., and A.S.C.; supervision: A.S.C.; funding acquisition: A.S.C.; investigation: K.M.; formal analysis: K.M.; writing-original draft preparation: K.M. and A.S.C.; writing—review and editing: K.M., A.S.C., C.M.H., S.P.C., and M.E.A.

Funding: This study was funded by the US Department of Agriculture, Forest Service, Southwestern Region grant number 10-DG-11031600-049, modification 002.

Acknowledgments: Appreciation is extended to the wildland firefighters that volunteered to participate in this study and to Wesley Page for comments on earlier drafts.

Conflicts of Interest: The authors declare no conflict of interest. The funders had no role in the design of the study; in the collection, analyses, or interpretation of data; in the writing of the manuscript, or in the decision to publish the results.

\section{References}

1. Meddens, A.J.H.; Hicke, J.A.; Ferguson, C.A. Spatiotemporal patterns of observed bark beetle-caused tree mortality in British Columbia and the western United States. Ecol. Appl. 2012, 22, 1876-1891. [CrossRef] [PubMed]

2. WFLC. Western Bark Beetle Assessment: A Framework for Cooperative Forest Stewardship; Western Forestry Leadership Coalition: Denver, CO, USA, 2009.

3. USDA Forest Service. Western Bark Beetle Strategy: Human Safety, Recovery, and Resiliency; U.S. Department of Agriculture, Forest Service: Washington, DC, USA, 2011.

4. Jenkins, M.J.; Hebertson, E.; Page, W.G.; Jorgensen, C.A. Bark beetles, fuels, fires, and implications for forest management in the Intermountain West. For. Ecol. Manag. 2008, 254, 16-34. [CrossRef]

5. Simard, M.; Romme, W.H.; Griffin, J.M.; Turner, M.G. Do mountain pine beetle outbreaks change the probability of active crown fire in lodgepole pine forests? Ecol. Monogr. 2011, 81, 3-24. [CrossRef] 
6. Jenkins, M.J.; Page, W.G.; Hebertson, E.G.; Alexander, M.E. Fuels and fire behavior dynamics in bark beetle-attacked forests in Western North America and implications for fire management. For. Ecol. Manag. 2012, 275, 23-34. [CrossRef]

7. Hicke, J.A.; Johnson, M.C.; Hayes, J.L.; Preisler, K. Effects of bark-beetle caused tree mortality on wildfire. For. Ecol. Manag. 2012, 271, 81-89. [CrossRef]

8. Hoffman, C.; Morgan, P.; Mell, W.; Parsons, R.; Strand, E.K.; Cook, S. Numerical simulation of crown fire hazard immediately after bark beetle-caused mortality in lodgepole pine forests. For. Sci. 2012, 58, 178-188. [CrossRef]

9. Hoffman, C.M.; Morgan, P.; Mell, W.; Parsons, R.; Strand, E.; Cook, S. Surface fire intensity influences simulated crown fire behavior in lodgepole pine forests with recent mountain pine beetle-caused tree mortality. For. Sci. 2013, 59, 390-399. [CrossRef]

10. Page, W.G.; Jenkins, M.J.; Runyon, J.B. Mountain pine beetle attack alters the chemistry and flammability of lodgepole pine foliage. Can. J. For. Res. 2012, 42, 1631-1647. [CrossRef]

11. Linn, R.R.; Sieg, C.H.; Hoffman, C.M.; Winterkamp, J.L.; McMillin, J.D. Modeling wind fields and fire propagation following bark beetle outbreaks in spatially-heterogeneous pinyon-juniper woodland fuel complexes. Agric. For. Meteorol. 2013, 173, 139-153. [CrossRef]

12. Hoffman, C.M.; Linn, R.; Parsons, R.; Sieg, C.; White, J. Modeling the effect of spatial and temporal dynamics following a mountain pine beetle outbreak on wind flow and potential fire behavior in a lodgepole pine forest. Agric. For. Meteorol. 2015, 204, 79-93. [CrossRef]

13. Sieg, C.H.; Linn, R.R.; Pimont, F.; Hoffman, C.M.; McMillin, J.D.; Winterkamp, J.; Baggett, L.S. Fires following bark beetles: Factors controlling severity and disturbance interactions in ponderosa pine. Fire Ecol. 2017, 13, 1-23. [CrossRef]

14. Hart, S.J.; Schoennagel, T.; Veblen, T.T.; Chapman, T.B. Area burned in the western United States is unaffected by recent mountain pine beetle outbreaks. Proc. Natl. Acad. Sci. USA 2015, 112, 4375-4380. [CrossRef] [PubMed]

15. Page, W.G.; Alexander, M.E.; Jenkins, M.J. Wildfire's resistance to control in mountain pine beetle-attacked lodgepole pine forests. For. Chron. 2013, 89, 783-794. [CrossRef]

16. Calkin, D.E.; Venn, T.; Wibbenmeyer, M.; Thompson, M.P. Estimating US federal wildland fire managers' preferences towards competing strategic suppression objectives. Int. J. Wildland Fire 2013, 22, 212-222. [CrossRef]

17. Byron, E. Firefighters Warn New Fires May Burn in Mysterious Ways. Helena Independent Record: Helena, MT, USA. Available online: http://helenair.com/news/firefighters-warn-new-fires-burn-in-mysterious-ways/ article_f9e71da0-76df-11e0-9ec6-001cc4c002e0.html (accessed on 16 December 2015).

18. Weick, K.E. The collapse of sensemaking in organizations: The Mann Gulch disaster. Adm. Sci. Q. 1993, 38, 628-652. [CrossRef]

19. Durbin, T.J.; Bendixsen, C.G.; Jensen-Ryan, D.; Molzer, A.; Strauss, S. The dangerous middle: Situational awareness and worker perception of beetle kill. J. Agromed. 2019, 24, 157-166. [CrossRef] [PubMed]

20. Louis, M.R. Surprise and sensemaking: What newcomers experience in entering unfamiliar organizational settings. Adm. Sci. Q. 1980, 25, 226-251. [CrossRef] [PubMed]

21. Klein, G.; Phillips, J.K.; Rall, E.L.; Peluso, D.A. A data-frame theory of sensemaking. In Expertise Out of Context, Proceedings of the Sixth International Conference on Naturalistic Decision Making, Pensacola Beach, FL, USA, 15-17 May 2003; Hoffman, R.R., Ed.; Taylor and Francis: New York, NY, USA, 2007; pp. 113-155.

22. Desmond, M. On the Fireline: Living and Dying with Wildland Firefighters; The University of Chicago Press: Chicago, IL, USA, 2007.

23. Kodas, M. Megafire: The Race to Extinguish a Deadly Epidemic of Flame; Houghton Mifflin Harcourt Publishing: New York, NY, USA, 2017.

24. Wall, T.; Brown, T.; Nauslar, N. Fire Stories-Understanding Wildland Firefighters' Perceptions of Unpredictable and Extreme Fire Behavior; Desert Research Institute: Reno, NV, USA, 2018; p. 27.

25. Weick, K.E.; Sutcliffe, K.M.; Obstfeld, D. Organizing for high reliability: Processes of collective mindfulness. In Research in Organizational Behavior; Sutton, R.S., Straw, B.M., Eds.; Jai Press: Stanford, CT, USA, 1999; pp. 81-123. 
26. Black, A.E.; McBride, B.B. Assessing High Reliability Practices in Wildland Fire Management: An Exploration and Benchmarking of Organizational Culture; Research Note RMRS-RN-55; US Department of Agriculture, Forest Service, Rocky Mountain Research Station: Fort Collins, CO, USA, 2013.

27. Alexander, M.E.; Thomas, D.A. Wildland fire behavior case studies and analyses: Value, approaches, and practical uses. Fire Manag. Today 2003, 63, 4-8.

28. Thomas, D.A. A case for fire behavior case studies. Wildfire 1994, 3, 45-47.

29. Alexander, M.E.; Thomas, D.A. Wildland fire behavior case studies and analyses: Other examples, methods, reporting standards, and some practical advice. Fire Manag. Today 2003, 63, 4-12.

30. Alexander, M.E.; Taylor, S.W. Wildland fire behavior case studies and the 1938 Honey Fire controversy. Fire Manag. Today 2010, 70, 15-25.

31. Weick, K.; Sutcliffe, K.K.; Obstfeld, D. Organizing and the process of sensemaking. Organ. Sci. 2005, 16, 409-421. [CrossRef]

32. Klein, G.; Calderwood, R.; Clinton-Cirocco, A. Rapid decision making on the fire ground: The original study plus a postscript. J. Cogn. Eng. Decis. Mak. 2010, 4, 186-209. [CrossRef]

33. Landgren, J. Supporting fire crew sensemaking enroute to incidents. Int. J. Emerg. Manag. 2005, 2, $176-188$. [CrossRef]

34. Cohn, J.P.; Carroll, M.S.; Kumagai, Y. Evacuation behavior during wildfires: Results of three case studies. West. J. Appl. For. 2006, 21, 39-48.

35. Moriarty, K. Firefighter Observations on Mountain Pine Beetle Post-Outbreak Lodgepole Pine Fires: Expectations, Surprises, and Decision-Making. Master's Thesis, Department of Forest and Rangeland Stewardship, Colorado State University, Fort Collins, CO, USA, 2014.

36. Scott, J.; Carrington, P.J. (Eds.) The SAGE Handbook of Social Network Analysis; Sage Publications: Thousand Oaks, CA, USA, 2011.

37. Strauss, A.; Corbin, J. Basics of Qualitative Research: Grounded Theory Procedures and Techniques, 3rd ed.; Sage Publications: Thousand Oaks, CA, USA, 2008.

38. Hutchinson, A.J.; Johnston, L.H.; Breckon, J.D. Using QSR-NVivo to facilitate the development of a grounded theory project: An account of a worked example. Int. J. Soc. Res. Methodol. 2010, 13, 283-302. [CrossRef]

39. Boeije, H. A purposeful approach to the constant comparative method in the analysis of qualitative interviews. Qual. Quant. 2002, 36, 391-409. [CrossRef]

40. Gleason, P. LCES-A key to safety in the wildland fire environment. Fire Manag. Notes 1991, 52, 9.

41. Leuschen, T.; Frederick, K. The consumption strategy: Increasing safety during mopup. Fire Manag. Notes 1999, 59, 30-34.

42. NWCG. Design and Delivery of Tactical Decision Games Sand Table Exercises: Leadership Toolbox Reference TDGS/STEX Workbook; National Wildfire Coordinating Group: Washington, DC, USA, 2003.

43. Tourangeau, R. Remembering what happened: Memory errors and survey reports. In The Science of Self-Report: Implications for Research and Practice; Stone, A.A., Bacharach, C.A., Jobe, J.B., Kurtzman, H.S., Cain, V.S., Eds.; Lawrence Erlbaum Associates, Inc.: Mahwah, NJ, USA, 1999; pp. $29-48$.

44. Yow, V.R. Recording Oral History: A Guide for the Humanities and Social Sciences; Altamira Press: Walnut Creek, CA, USA, 2005.

45. Lieberman, H.R.; Bathalon, G.P.; Falco, C.M.; Morgan, C.A.; Niro, P.J.; Tharion, W.J. The fog of war: Decrements in cognitive performance and mood associated with combat-like stress. Aviat. Space Environ. Med. 2005, 76, 7-14.

46. Jeong, H.S.; Brower, R.S. Extending the present understanding of organizational sensemaking: Three stages and three contexts. Adm. Soc. 2008, 40, 223-252. [CrossRef]

47. Brower, R.S.; Choi, S.O.; Jeong, H.S.; Dilling, J. Forms of inter-organizational learning in emergency management networks. J. Homel. Secur. Emerg. Manag. 2009, 6, 1547-7355. [CrossRef]

48. Burrows, N.D. Predicting Blow-Up Fires in the Jarrah Forest; Technical Paper 12; Western Australia Forests Department: Perth, WA, Australia, 1984; p. 27.

49. Gisborne, H.T. Fundamentals of fire behavior. Fire Control Notes 1948, 9, 13-24.

50. Scott, C.W.; Trethewey, A. Organizational discourse and the appraisal of occupational hazards: Interpretive repertoires, heedful interrelating, and identity at work. J. Appl. Commun. Res. 2008, 36, 298-317. [CrossRef]

51. Thomas, D.; Fox, R.; Miller, C. Voices from the field: Wildland fire managers and high-reliability organizing mindfulness. Soc. Nat. Resour. 2015, 28, 825-838. [CrossRef] 
52. Jahn, J.L.S. Adapting safety rules in a high reliability context: How wildland firefighting workgroups ventriloquize safety rules to understand hazards. Manag. Commun. Q. 2016, 30, 362-389. [CrossRef]

53. Weick, K.E. Enacted sensemaking in crisis situations. J. Manag. Stud. 1988, 25, 305-317. [CrossRef]

54. Stephens, S.L.; Burrows, N.; Buyantuyev, A.; Gray, R.W.; Keane, R.E.; Kubian, R.; Liu, S.; Seijo, F.; Shu, L.; Tolhurst, K.G.; et al. Temperate and boreal forest mega-fires: Characteristics and challenges. Front. Ecol. Environ. 2014, 12, 115-122. [CrossRef]

55. Tedim, F.; Leone, V.; Amraoui, M.; Bouillon, C.; Coughlan, M.R.; Delogu, G.M.; Fernandes, P.M.; Ferreira, C.; McCaffrey, S.; McGee, T.K.; et al. Defining extreme wildfire events: Difficulties, challenges, and impacts. Fire 2018, 1, 9. [CrossRef]

56. Klutsch, J.G.; Battaglia, M.A.; West, D.R.; Costello, S.L.; Negron, J.F. Evaluating potential fire behavior in lodgepole pine-dominated forests after a mountain pine beetle epidemic in north-central Colorado. West. J. Appl. For. 2011, 26, 101-109.

57. Kulakowski, D.; Jarvis, D. The influence of mountain pine beetle outbreaks and drought on severe wildfires in northwestern Colorado and southern Wyoming: A look at the past century. For. Ecol. Manag. 2011, 262, 1686-1696. [CrossRef]

58. Stephens, S.L.; Collins, B.M.; Fettig, C.J.; Finney, M.A.; Hoffman, C.M.; Knapp, E.E.; North, M.P.; Safford, H.; Wayman, R.B. Drought, tree mortality, and wildfire in forests adapted to frequent fire. Bioscience 2018, 68, 77-88. [CrossRef]

59. Page, W.G.; Jenkins, M.J.; Alexander, M.E. Crown fire potential in lodgepole pine forests during the red stage of mountain pine beetle attack. Forestry 2014, 87, 347-361. [CrossRef]

60. Schoennagel, T.; Veblen, T.T.; Negron, J.F.; Smith, J.M. Effects of mountain pine beetle on fuels and expected fire behavior in lodgepole pine forests. PLoS ONE 2012, 7, e30002. [CrossRef] [PubMed]

61. Jolly, M.W.; Parsons, R.A.; Hadlow, A.M.; Cohn, G.; McAllister, S.S.; Popp, J.B.; Hubbard, R.M.; Negron, J.F. Relationships between moisture, chemistry, and ignition of Pinus contorta needles during the early stages of mountain pine beetle attack. For. Ecol. Manag. 2012, 269, 52-59. [CrossRef]

62. Page, W.G.; Jenkins, M.J.; Alexander, M.E. Foliar moisture content variations in lodgepole pine over the diurnal cycle during the red stage of mountain pine beetle attack. Environ. Model. Softw. 2013, 49, 98-102. [CrossRef]

63. Cruz, M.G.; Alexander, M.E. Assessing crown fire potential in coniferous forests of western North America: A critique of current approaches and recent simulation studies. Int. J. Wildland Fire 2010, 19, 377-398. [CrossRef]

64. Hood, S.M.; Keane, R.E.; Smith, H.Y.; Egan, J.; Holsinger, L. Chapter 13-Conventional fire behavior modeling systems are inadequate for predicting fire behavior in bark beetle-impacted forests (Project INT-EM-F-11-03). In Forest Health Monitoring: National Status, Trends, and Analysis 2017; General Technical Report SRS-GTR-233; Potter, K.M., Conkling, B.L., Eds.; U.S. Department of Agriculture, Forest Service, Southern Research Station: Asheville, NC, USA, 2018; pp. 167-176.

65. Perrakis, D.D.B.; Lanoville, R.A.; Taylor, S.W.; Hicks, D. Modeling wildfire spread in mountain pine beetle-affected forest stands, British Columbia, Canada. Fire Ecol. 2014, 10, 10-35. [CrossRef]

66. Parker, R.; Vitalis, A.; Walker, R.; Riley, D.; Pearce, H.G. Measuring wildland fire fighter performance with wearable technology. Appl. Ergon. 2017, 59, 34-44. [CrossRef]

(C) 2019 by the authors. Licensee MDPI, Basel, Switzerland. This article is an open access article distributed under the terms and conditions of the Creative Commons Attribution (CC BY) license (http://creativecommons.org/licenses/by/4.0/). 